BY TONY J. PITCHER, MALCOLM R. CLARK, . TELMO MORATO, AND REG WATSON

\title{
Seamount Fisheries:
}
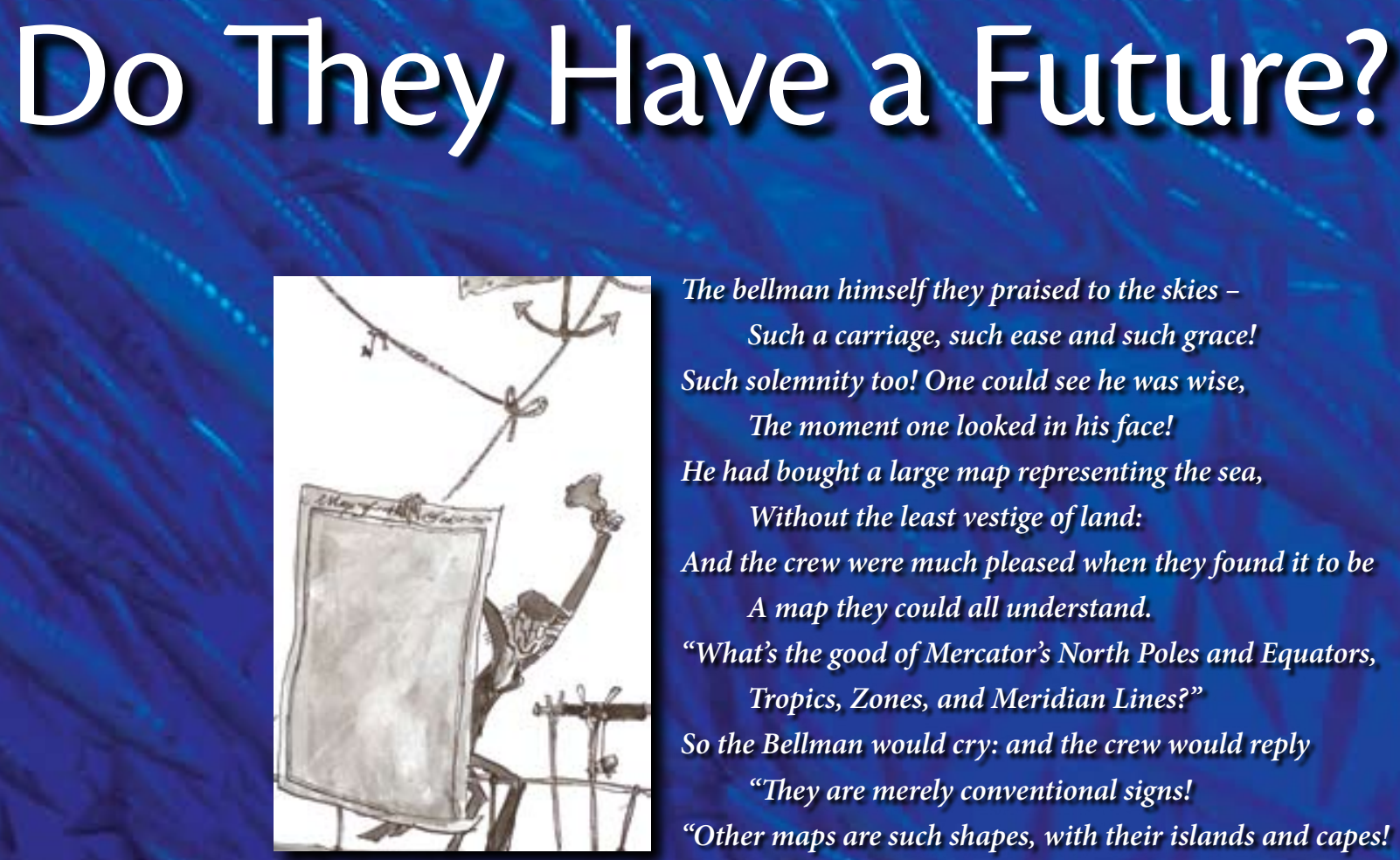

The bellman himself they praised to the skies -

Such a carriage, such ease and such grace!

Such solemnity too! One could see he was wise,

The moment one looked in his face!

He had bought a large map representing the sea,

Without the least vestige of land:

And the crew were much pleased when they found it to be

A map they could all understand.

"What's the good of Mercator's North Poles and Equators,

Tropics, Zones, and Meridian Lines?"

So the Bellman would cry: and the crew would reply

"They are merely conventional signs!

"Other maps are such shapes, with their islands and capes!

But we've got our brave Bellman to thank"

(So the crew would protest) "that he's bought us the best-

A perfect and absolute blank!"

From Fit the Second in The Hunting of the Snark: An Agony in Eight Fits by Lewis Carroll, 1876. Illustration by Quentin Blake, for the Folio Society 1976 edition of The Hunting of the Snark

() The Folio Society.

Yellowmouth barracuda (Sphyraena viridensis)

on top of Princesa Alice Seamount (Azores,

Northeast Atlantic). Photo Credits: J. Fontes/ImagDOP 


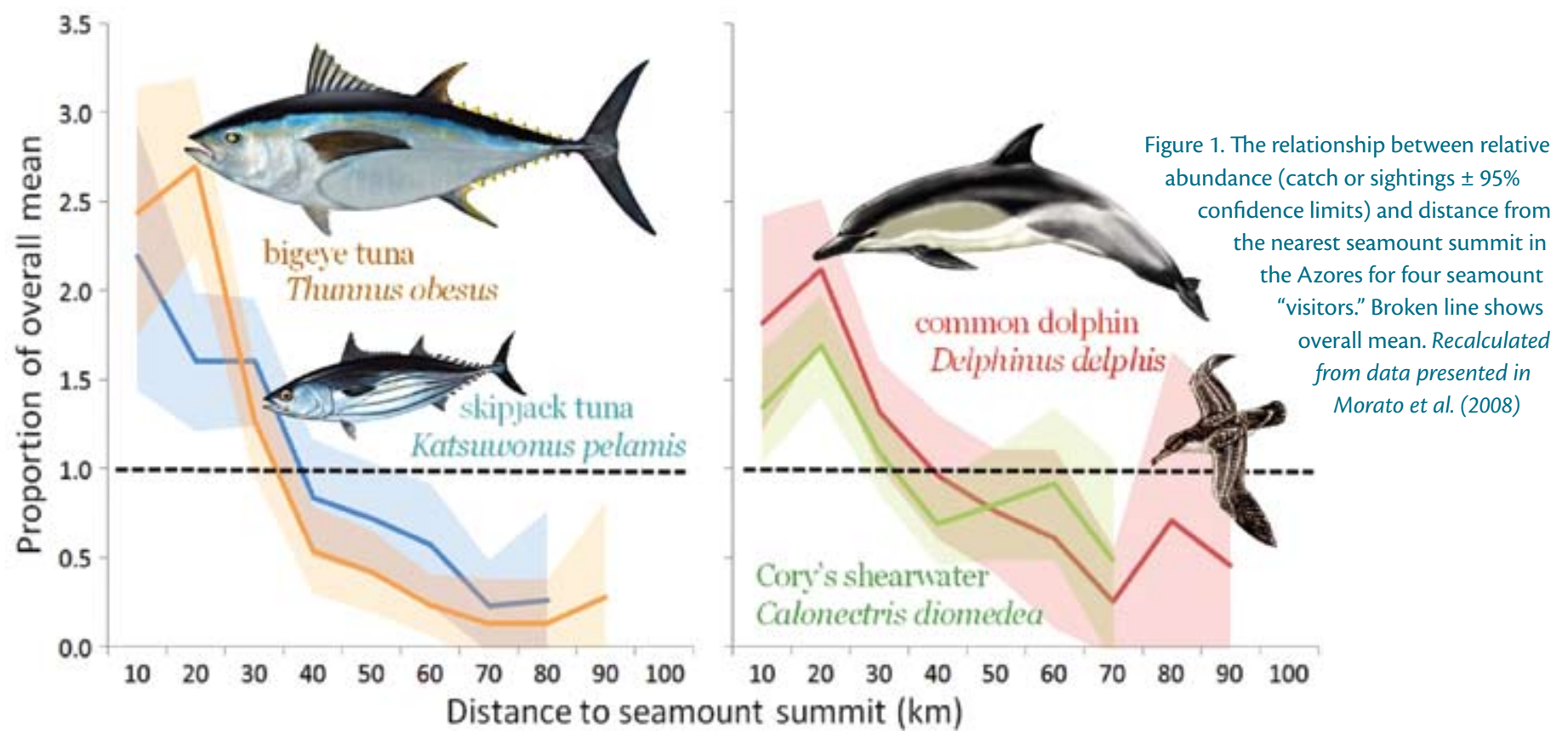

ABSTRACT. Today, seamount fish populations are in trouble following a 30-year history of overexploitation, depletion, and collapse, with untold consequences for global biodiversity and the complex, delicate, but poorly understood, open-ocean food webs. Seamount fishes are especially vulnerable to fishing because their "boomand-bust" life history characteristics can be exploited by heavy, high-technology fisheries. We estimate present global seamount catches to be about 3 million tonnes per annum and increasing-vastly in excess of estimated sustainable levels. Unfortunately, most seamount fisheries are unmanaged. In a few developed countries, precautionary management regimes have recently been introduced, including protection from bottom trawling. Small-scale artisanal fisheries using less-harmful fishing gear, spatial closures, and low catch levels provide an attractive model for improved seamount fishery management that could foster the reconstruction of previously damaged seamount ecosystems. Such restored systems might one day support a substantial global sustainable fishery, although, like many other fisheries, the prognosis is poor.

\section{INTRODUCTION}

In order to know where you might go, it helps a lot to know where you are starting from and how you got there. It is bewildering how much fisheries policy, like Lewis Carroll's Bellman and his crew, fails to meet this rather obvious "road map" approach. Seamounts, of which there an awful lot however you count them ${ }^{1}$, have produced some large and stunningly profitable fish catches (Clark et al., 2007) that have led to false expectations that such returns might be sustainable. In fact, the long-lived organisms that typically take advantage of the delicately balanced trophic webs on seamounts (e.g., Pitcher and Bulman, 2007) are evolutionarily adapted to "feast or famine" or consistently sparse feeding conditions, or are part of hard-to-measure transient communities of visiting fish, mammal, and bird predators that rapidly move on to new grazing grounds (Figure 1; Morato et al., 2008). These life history features make seamount fish populations extremely vulnerable to heavy fishing, and they cannot sustain heavy local exploitation. But there is little detailed knowledge of the fisheries ecology of seamounts, partly because it is difficult to conduct research on them, and hence there are few preexploitation baselines. In addition, much of the past overfishing has occurred in the remote open ocean and high seas, areas where there is no effective jurisdiction, catch data, or monitoring.

Collapse and depletion of many historical inshore and shelf groundfish stocks in the late 1900s encouraged

${ }^{1}$ An average of about 60 large, > 1-km-tall seamounts per Exclusive Economic Zone, and about 10 times that number of small, >0.1-km-tall seamounts (Wessel, 2007; Kitchingman et al., 2007). 


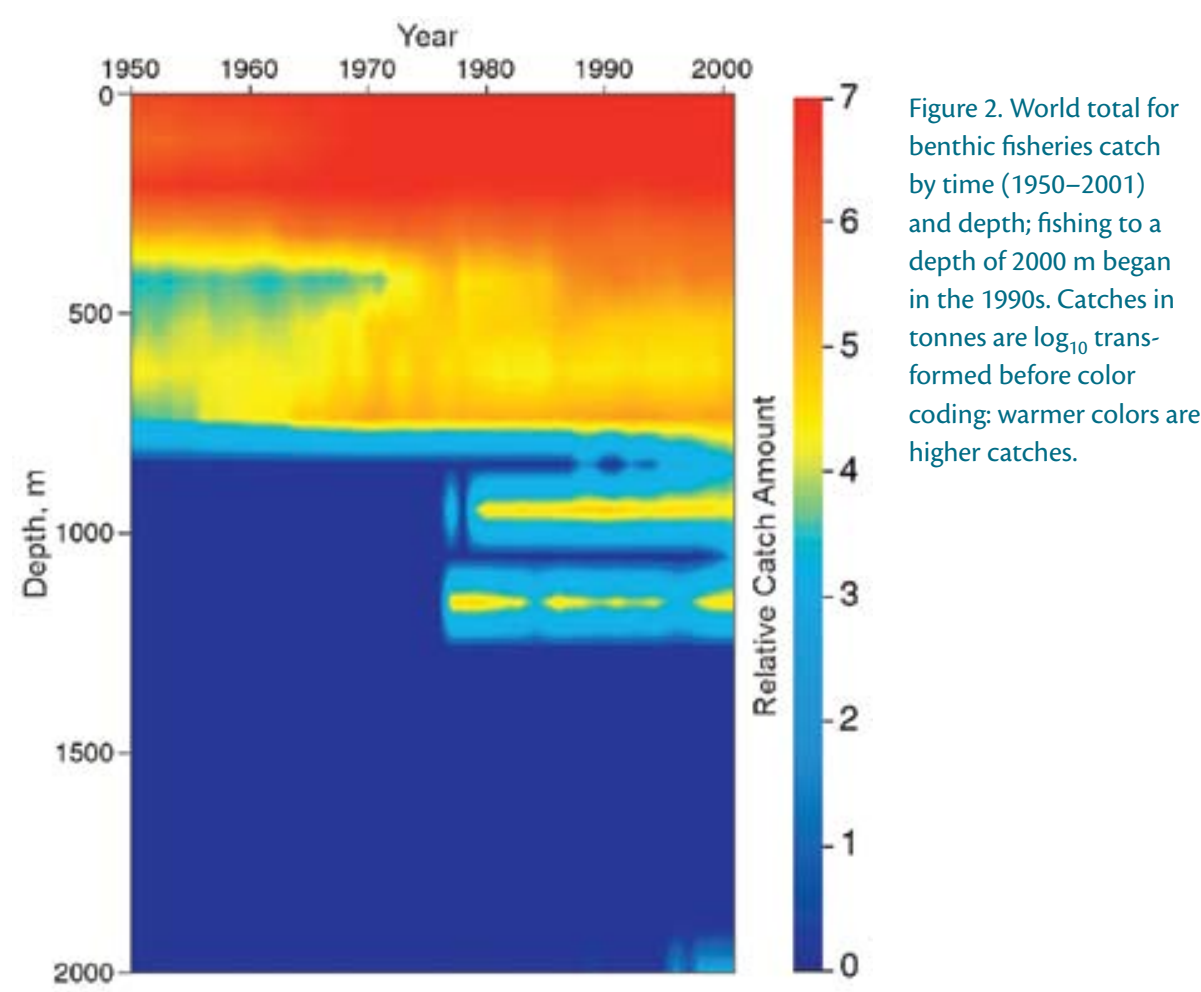

fisheries to expand into deeper water and, in particular, to seamounts. Since the 1970s, advanced gear technology has enabled fishing in increasingly compromised overfished shelf waters, in deeper water, and on small, steep, and rough seamount flanks that previously could not be trawled (Morato et al., 2006b; Figure 2). Fishing operations have long been known to have serious physical impacts on seamount habitats (Clark and Koslow, 2007). Longlines, gillnets, traps, and pots all have some effect on seafloor habitats, but bottom trawling is the most widely recognized for causing considerable damage to the seafloor and associated faunal communities (e.g., Johnson, 2002; Watling and Norse, 1998). The ground gear used to protect the trawl nets from damage on rough seafloor is large and heavy, and there are obvious direct impacts caused by physical disruption, but there are also indirect effects of fishing, such as sediment resuspension and mixing, and discharge of processing waste (Clark and Koslow, 2007). There have been surprisingly few studies on deepwater fishing impacts (e.g., Gage

Tony J. Pitcher (pitcher.t@gmail.com) is Professor of Fisheries, Fisheries Centre, Aquatic Ecosystems Research Laboratory, University of British Columbia, Vancouver, Canada.

Malcolm R. Clark is Principal Scientist, National Institute of Water \& Atmospheric Research, Wellington, New Zealand. Telmo Morato is Research Fellow, Department of Oceanography and Fisheries, University of the Azores, Horta, Faial, Portugal, and is also with the Oceanic Fisheries Program, Secretariat of the Pacific Community, Noumea, New Caledonia. Reg Watson is Senior Research Fellow, Sea Around Us Project, Hobart, Tasmania, Australia (project headquarters is located at the University of British Columbia, Vancouver, Canada).

et al., 2005), especially on seamounts, given the amount of fishing conducted on them in recent years. For example, "compare and contrast" studies of the benthic communities on fished and unfished seamounts off Australia and New Zealand have demonstrated reductions in the structural complexity of benthic habitats, as well as lower species composition and abundance (J.A. Koslow et al., 2001; Clark and O'Driscoll, 2003; Clark and Rowden, 2009). Sessile fauna, such as cold-water corals that can form reef-like structures on the summits and upper flanks of deep seamounts, are particularly vulnerable to damage by heavy ground gear (Rogers et al., 2007). These animals can form biogenic habitat for many other species, and may be slow-growing and hundreds of years old, so any recovery from impact is slow (e.g., Probert, 1999; Freiwald et al., 2004; Kaiser et al., 2006). Waller et al. (2007) recently reported the destruction of habitat on the tops of seamounts in the Corner Rise area.

This article reviews our attempts to deduce what has happened to seamount fisheries, describes what we know of their present status and management, looks at how they might be better managed, and employs a global estimation procedure to suggest what sustainable fishery yields seamounts might provide.

\section{SEAMOUNT FISHERIES}

Using a global spatial algorithm that estimates catches within $20 \mathrm{~km}$ of known seamount positions, Watson et al. (2004, 2007; see Sidebar 1) show that for 13 primary (obligate) seamount fish species, estimated catches peaked at about 1.2 million tonnes per year 
in the mid 1990s, worth on landing about $\$ 2$ billion, while the catches of secondary seamount species (29 species of facultative ${ }^{2}$ visitors to seamount food webs) are still increasing, and amount to about 3 million tonnes per year, with a total landed value of about $\$ 4.4$ billion. In Figure 3, which maps seamount fisheries by decade, the increasingly reddish (hotter) colors demonstrate higher catches. Unfortunately, Watson et al. (2004) did not include in their catch mapping the chronology of expansion from the continental slopes to more and more distant seamount areas, so this trend is not well captured here, but it has been shown conclusively for orange roughy fisheries. Nevertheless, there appears to be a general expansion of seamount fishing in southern latitudes. The methods used to calculate these figures can likely be refined, but we are confident that they are indicative of the relative scale of seamount catches (see Sidebar 1).

\section{Large-Scale Fisheries}

Catch reconstructions pieced together from many data sources for 29 seamount regions show that much of the exploitation up until the 1990s was prosecuted by large-scale fishing fleets (mainly from Soviet bloc and Asian countries) that were targeting aggregations of food fish on seamounts with bottom and mid-water trawls (Clark et al., 2007). Catch data can be hard to find because they are often reported by port of landing in the fleets' home countries and their origin attributed only to

\footnotetext{
${ }^{2}$ Here, "facultative" is used as an ecological term meaning contingent, or capable of living at a seamount or elsewhere, as opposed to "obligate," meaning fish that have to live at a seamount.
}

one of the United Nation's 21 global areas (see http://www.seaaroundus. org/eez/FAOarea.htm). Moreover, many jurisdictions change over time (e.g., the Soviet Union). Nevertheless, it is possible to piece together some key features of this history, such as the typical "boom-and-bust" situation in large-scale seamount fisheries (Figure 4). In some fisheries, such as those on the Tasmanian seamounts; the Emperor, Hawaiian, and Southwest Indian ridges; the northern Mid-Atlantic Ridge; and the Madeira-Canaries area, the maximum annual catches were relatively high but were not sustained for

\section{Sidebar 1. Algorithm for Estimating Fishery Catches at Seamounts}

Scientists outside of the fishery field are often surprised that much of the "data" on catches are not well known and have to be estimated. Fisheries statistics are available for most of the world's fisheries landings from a number of institutions, including the Food and Agriculture Organization (FAO) of the United Nations and its regional bodies, the International Council for the Exploration of the Sea (ICES), the Commission for the Conservation of Antarctic Marine Living Resources (CCAMLR), and the Northwest Atlantic Fisheries Organization (NAFO). However, these data mostly concern where fish were landed and sold, whereas information about where the fish were caught is often very vague or missing altogether (Watson et al., 2004). In addition to these "reported" catches, unreported discards and illegal fish catches have only recently been estimated globally (Agnew et al., 2009). On average, they add at least $50 \%$ to the reported landings. Hence, we used an algorithm that estimates catch in small spatial areas based on reported catches, species distributions, international fishery agreements, and other information.

Global catch rates (tonnes $\mathrm{km}^{-2} \mathrm{yr}^{-1}$ ) mapped into half-degree zones were constructed with rule-based procedures (Watson et al., 2004) developed by the Sea Around Us (SAU) project based at the Fisheries Centre of the University of British Columbia, Canada (http://www.seaaroundus.org). Available fisheries data were harmonized by removing overlaps and standardizing codes from a wide range of sources (see above), and employing many reconstructed national data sets (Zeller and Pauly, 2007) to produce a representative database of global fisheries landings (see http://www.seaaroundus.org). We also used additional databases of fishing access arrangements compiled by SAU from FAO and other sources, observed national fleet fishing patterns (Watson et al., 2004), and incorporated extensive information on the geographical distribution and ecology of over 2000 commercial marine fish species from the literature and museum collections (Close et al., 2006). The original spatially coarse fisheries landings data records were assigned to a grid of 30-minute latitude $\times 30$-minute longitude spatial cells from 1950 to 2004. For this paper, fishery catches were tallied from cells that contained at least one seamount, for zones within $20 \mathrm{~km}$ of a known seamount. Figure 3 globally maps these estimated seamount catch levels by decade. 


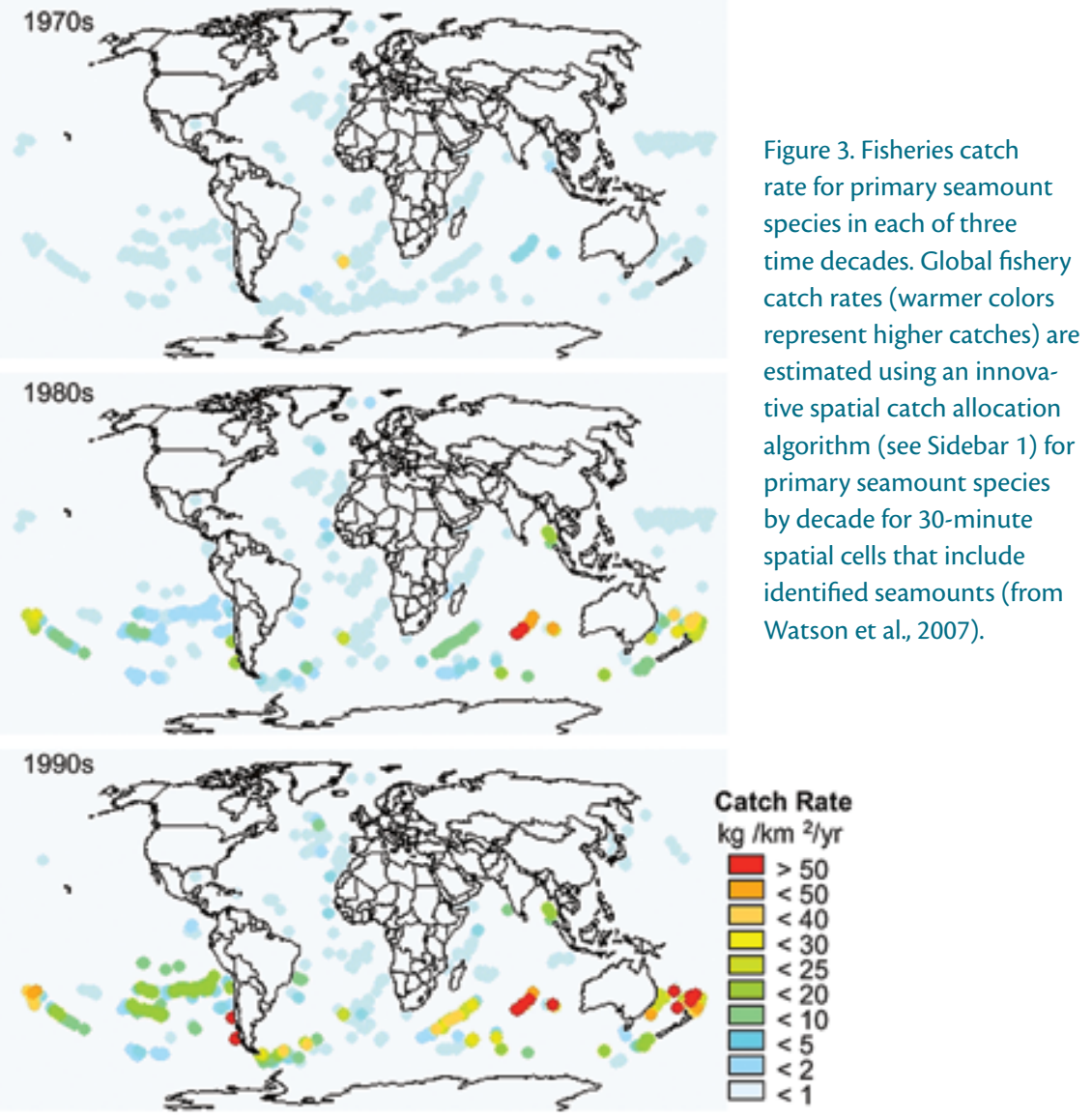

long. The major bottom species in these fisheries seem to have been pelagic armourhead (Pseudopentaceros wheeleri), alfonsino (Beryx splendens), roundnose grenadier (Coryphaenoides rupestris), cardinalfish (Epigonus spp.), orange roughy (Hoplostethus atlanticus), oreos (Allocyttus niger, Pseudocyttus maculatus), toothfish (Dissostichus spp.), and notothenid cods (Notothenia spp.). The largest of these trawl fisheries occurred in the Pacific, where an estimated 800,000 tonnes of pelagic armourhead were taken between 1968 and 1982 (T. Koslow, 2007; Clark et al., 2007). The other major large-scale bottom fisheries have been for roundnose grenadier on the Mid-Atlantic Ridge in the 1970s and 1980s (Vinnichenko, 2002), and for orange roughy in the southwestern Pacific from the 1980s to present (Clark, 1999; Francis and Clark, 2005). Over this period, at least 2.2 million tonnes of fish were extracted from seamounts from the major world regions (Clark et al., 2007), almost all of them taken for human food and sold to an unknowing public under a bewildering variety of market names. Although many seamounts are not yet officially described (over 6000 are predicted with summit depths less than $2 \mathrm{~km}$ ), this 40-year history of uncontrolled fishing around the world forces the authors to think it unlikely that there are many seamounts supporting commercial fish that have not yet been heavily fished.

However, few of these large-scale seamount fisheries have proven sustainable. Both within and among regions, serial depletion ${ }^{3}$ is evident as the fishing fleets moved on from one seamount to the next (e.g., off New Zealand; Clark, 1999) and often to another target species as the initial stocks were overexploited (e.g., pelagic armourhead to alfonsino; Sasaki 1986; see many examples in Figure 4). Today, the authors consider that sustainable fishery catches come from only a very few seamounts, almost all within the Exclusive Economic Zones (EEZs) of reasonably well-managed, developed countries (e.g., New Zealand and the United States; see Pitcher et al., 2009). These fisheries are typically low volume and high value. And even here, evidence of true sustainability with assured recruitment of juvenile fish can be disputed.

\section{Artisanal Fisheries}

About one quarter of a million tonnes of fish are caught annually by small-scale local fisheries on seamounts (Marques da Silva and Pinho, 2007). Most of these artisanal fisheries target bottom fish, but half of the estimated seamount catch comprises tuna species, which congregate around seamounts (Morato et al., 2008). Therefore, seamounts provide livelihoods for local fishers in several parts of the world, most notably in the Azores, Madeira, the Seychelles, Hawai' i, and many Pacific volcanic mid-ocean islands that are themselves seamounts that have emerged above the ocean

\footnotetext{
${ }^{3}$ A term referring to the successive overfishing of new fishing grounds. As fish yields decline with overfishing, new fishing grounds are sought, each of which is overfished, thus triggering the search for yet more new fishing grounds.
} 

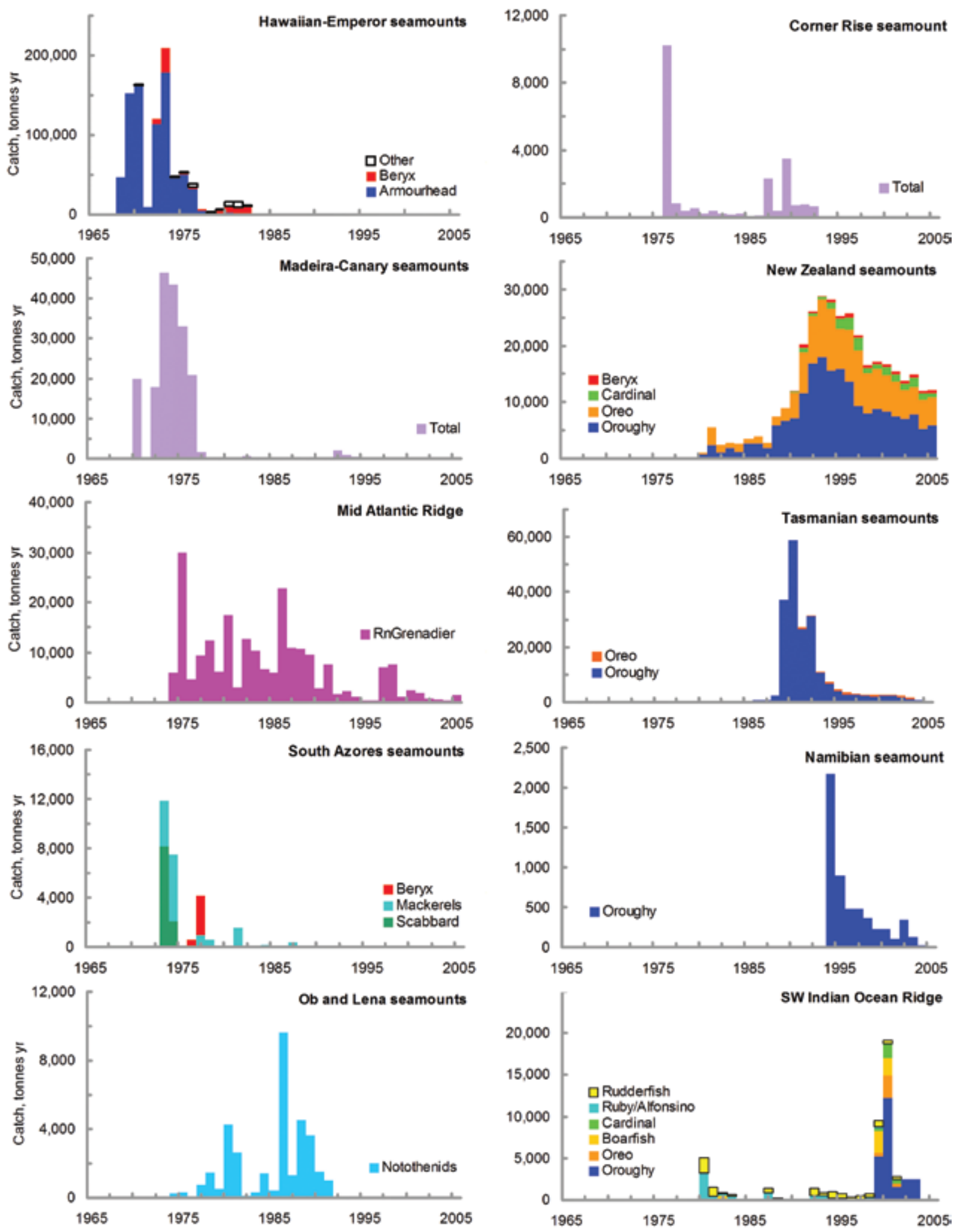

Figure 4. Historical fishery catches (tonnes $\mathrm{yr}^{-1}$ ) from 10 key seamount fishery areas around the world. A variety of seamount fishery target species are shown. Data used in this figure derive from many sources, some of which are unpublished; full details are provided for these areas, and 19 others globally, in Clark et al. (2007). 
surface. The relative isolation of many of these islands makes small-scale fishing yields a major source of protein and income for local populations.

Contrary to the history of large-scale fishing on seamounts, many small-scale fisheries have existed for centuries and are good examples of long-term sustainable fishing. They are usually small-boat, hook-based fisheries employing gear such as handlines, pole-and-line, or small longlines. These artisanal fisheries thus have a number of attractive features that might be adopted in the sustainable management of all seamount fisheries, including no bottom trawling and reduced fishing effort, creating de facto no-fishing refuges. Management and compliance in these small-scale fisheries depends upon two factors. First, a thriving local fresh fish market that, for example, in the Azores, is provided by a European Union automated reverse auction system. ${ }^{4}$ Second, the political pressure to legislate and implement local regulations may be enhanced where local and indigenous fishers ${ }^{5}$ have a thriving local community. Some effective management measures have already been implemented to protect vulnerable seamount habitats. For example, bottom trawl bans have been declared in several seamount areas around the world, including the Azores, Madeira, the Canaries, Kiribati, Palau, Alaska's Aleutian Islands, and deep Mediterranean waters; around some specific seamounts (Santa Maria di Leuca and Eratosthenes seamounts); and around some seamounts in the North Atlantic, Southwest Pacific, and off the west coast of the United States. Ultimately, the only way to succeed in fisheries management is to stimulate responsible fishing and halt unsustainable fisheries before these fragile biological resources themselves vanish.

\section{UNDERSTANDING}

\section{SEAMOUNT EXPLOITATION}

Research tools such as trophic web and biogeochemical simulation models have been used to try to understand seamount exploitation (Fulton et al., 2007), despite considerable problems in tuning and validating these complex numerical models with field data. For example, whole ecosystem, mass-balance simulations show why seamount systems are so vulnerable. Autochthonous (i.e., local) seamount resources are not likely to be sufficient to support large amounts of seamount-aggregating fish and, moreover, local enhancement of primary productivity (through, for example, current retention phenomena) cannot sustain these biomasses. The models suggest that horizontal immigration of allochthonous (i.e., from elsewhere) micronekton (of around 95 tonnes per $\mathrm{km}^{2}$ per year, less than the average in most oceanic waters) may be sufficient to sustain the rich communities living on seamounts (Morato et al., 2009). These types of models can explicitly allow for evaluation of bycatch, habitat impacts, and anthropogenic and environmental interactions, aiding in the consideration of the implications of alternative policy scenarios and management strategies.

General results of preliminary seamount modeling analyses suggest that sustainable fisheries on seamounts will likely be very small in relation to past large catches. Protection at the level required under ecosystem-based management legislation can only ensue if ecological objectives outweigh economic ones. For example, many gear types, such as deepwater trawls and midwater and pelagic longlines, can have a strong negative impact on the deepwater ecosystem and require management control. Trophic web models suggest that sustainable exploitation of seamounts may be achieved by promoting smallscale fishing using nondestructive fishing methods such as tuna poleand-line, small pelagic fish fishing (in shallow depths), and small-scale bottom handline and longline fishing (which can be prosecuted at considerable depths). These fishing methods will potentially have a reduced impact in the ecosystem while providing livelihoods for local populations.

\section{CONSERVATION AND}

\section{MANAGEMENT}

Wide scientific and public concern about the adverse impacts of bottom trawling and the lack of seamount fishery sustainability has led, in recent years, to initiatives designed to improve their conservation and management at global, regional, and national levels (Probert et al., 2007). Management measures that have been implemented regionally and locally include no-take zones and marine protected areas with various levels of protection by zone and by fishing gear. These measures often started as closure of individual seamounts to specific fishing techniques (e.g., off New Zealand in 2001 when 19 seafloor features were protected from bottom trawling and dredging), but management has

\footnotetext{
${ }^{4} \mathrm{~A}$ computer-automated auction in which an item starts at a high price and reduces in steps until a bid occurs.

${ }^{5}$ Aboriginal and indigenous native peoples, such Maori, Sami, and Canadian First Nations.
} 
since evolved to include an ecosystem approach to fisheries management covering more nontarget species, larger areas, and a range of deep-sea habitats. This approach has lead to closure, or limited exploitation, of many areas off, for example, southern Australia, New Zealand (where over $30 \%$ of the EEZ has been recently protected from bottom trawling), and the Azores (where a 100 nautical mile box has been protected from trawling for over 20 years under a series of special EU Common Fisheries Policy agreements). Protective measures have also been taken in the Northeast Atlantic (e.g., through the North East Atlantic Fisheries Council, the OSPAR Convention, the International Commission for Exploration of the Seas, and the EU), the Northwest Atlantic, and the Northeast Pacific (e.g., Bowie Seamount Marine Protected Area in Canada and Davidson Seamount off California), as well as in waters off Alaska (where 1 million square kilometers is now protected) and Hawai $i$. In the eastern North Pacific, a significant seamount area of $388,000 \mathrm{~km}^{2}$ in the US EEZ has been closed to bottom trawling (NMFS, 2005). Less-specific management measures can also protect seamounts, such as precautionary fishing limit provisions under the Commission for the Conservation of Antarctic Marine Living Resources (CCAMLR), and depth limits that have been set for the Mediterranean Sea. As a result, some form of conservation has been applied to seamounts throughout many parts of the world. However, where there is significant existing fishing, commercial lobbies have prevented some proposed actions, such as increases in the number of proposed sites in the North Atlantic.
Shortcomings in the existing management are highlighted by Francis and Clark (2005) and Clark et al. (2010), and include conflicts over what is needed for fisheries management versus benthic habitat protection.

Managing seamounts inside EEZs has proven a hard enough task, but seamounts in the high seas present a more difficult challenge. Seamounts were identified by the United Nations General Assembly in 2006 as vulnerable, and recent agreement to and adoption of United Nations Food and Agriculture Organization (FAO) guidelines on management of deep sea fisheries in the high seas (FAO, 2008, 2009) are significant advances in recognizing the need for global action on seamount conservation. However, although the FAO guidelines and supporting documents (e.g., Rogers et al., 2008) contain specific recommendations, it can take for effectively managing fisheries in their region is far from stellar (Mora et al., 2009). In the recent past, considerable unreported fishery catches (on average, $50 \%$ of reported catch) on the high seas have been ascribed to serial depletion of seamounts (Agnew et al., 2009), and the situation has yet to show signs of improvement. It can be argued that there is often insufficient scientific information to advise management about remote high seas resources, but this should not be an excuse for inaction. If we do nothing, we are sure to see continued depletion of stocks and fisheries collapse, and disruption of seamount biodiversity and ecosystem function for generations to come.

As an integrated method for evaluating the current status of individual seamounts, Pitcher et al. (2007) propose an Ecosystem Evaluation Framework (EEF). In this three-part EEF, the first

\section{S 6 ...THE EVIDENCE PUT FORWARD HERE ARGUES THAT ALL SEAMOUNTS NEED RATIONAL MANAGEMENT, PROTECTION FROM TRAWLING, AND CONTROL OF OTHER TYPES OF FISHING IF THEY ARE NOT ONLY TO PROVIDE SUSTAINABLE FISHERIES BUT ALSO TO SERVE AS RESERVOIRS OF ABUNDANCE, PROPAGULES, AND BIODIVERSITY.}

considerable time for implementation, especially when some oceans are not covered by formal Regional Fisheries Management Organizations (RFMOs) at this time (e.g., North Pacific, South Pacific, southern Indian Ocean), even though the track record of most RFMOs part scores the extent of our knowledge about individual seamounts, including those cases where we know the extent of local enhancement of biomass and biodiversity. The second part of the EEF assesses the severity of a range of threats, mainly from fisheries but also from other 
anthropogenic threats, to the abundance and diversity of living organisms found at individual seamounts. A third part, currently under development, aims to quantify each attribute (see Box 6 on page 123 of this issue). EEF aims to focus attention on key missing data and on severe and emerging threats. However, the utility of this integrative framework will not be determined until a larger number of seamounts are covered.

If the world's seamounts were managed sustainably today, what fishery yields might be possible? Methods described by Cheung et al. (2009a, 2009b) established maximum sustainable yields (MSY) for all global commercial fishes based on a metabolic/trophic model (see Sidebar 2). These MSY values for seamount species, together with the proportion of global fish catch associated with seamounts from Watson et al. (2007; see Sidebar 1), allow us to make a preliminary global seamount MSY estimate that about 138,000 tonnes could be safely caught annually. An alternative method, outlined by Srinivasan et al. (2008; see Sidebar 2), produces upper and lower estimates of only 17,000 to 34,000 tonnes of sustainable annual catch. These values contrast with Watson et al.s (2007) estimate that the global catch of commercial species that comes from seamounts (2001 to 2004) is about 400,000 tonnes, suggesting that the current fishery take is well in excess of either of our MSY estimates for seamount species and will lead, at the very least, to further depletion. This assessment implies that the only viable policy for managing seamount fish populations is one of rebuilding and restoration.

We can work out viable ways to exploit restored seamount systems using new ecosystem-based techniques such

\section{Sidebar 2. Estimating the Maximum Sustainable Yield for Seamount Fish Stocks}

Although fishery assessments in the public domain provide sustainable yield estimates for major commercial fish populations in developed countries, maximum sustainable yield (MSY) estimates are not available for minor stocks, for most developing nations (Pitcher et al., 2009), and for fisheries associated with remote ocean areas where many seamounts are found. Although until recently thought difficult, techniques of meta-analysis can now provide MSY estimates for these previously intractable fish populations, including those associated with the world's seamounts. The technique integrates all that is known about the species' life and catch histories.

Cheung et al. (2009b) calculated MSY', which they defined as MSY from the exploited range of a species. The classic Schaefer surplus production fishery equation:

MSY $=($ Binf . $r) / 4$,

where $r$ is the intrinsic rate of population and Binf is the carrying capacity for this fish population, is related to the energy, E, available to a specific fish population based on

$E=g \cdot P \cdot T E Y-1$,

where $P$ is total primary production, TE is the transfer efficiency, and $\gamma$ is the proportion of energy at trophic level $\lambda$ that is used by the population (e.g., Ware, 2000).

The conclusion is that there is a useful relationship:

$\log M S Y^{\prime}=\log P^{\prime}-\mathrm{a} \cdot Y+\log g+g$, where $P^{\prime}$ is the primary production from the exploited range, and a and $g$ are constants. They fitted known catches to this relationship to estimate the parameters that allow sustainable yields from other stocks to be estimated.

Cheung et al. $(2005,2007)$ and Morato et al. $(2006 \mathrm{a})$ calculated the intrinsic vulnerability to fishing for commercial fish species based on a fuzzy logic expert system using life history (maximum length, age at first maturity, longevity, von Bertalanffy growth parameter $[\mathrm{K}]$, natural mortality and fecundity) and ecological characteristics (spatial behavior and geographic range). Generally, the lower the vulnerability, the higher the production or long-term yield that can be extracted sustainably from a fish stock. (Fish species estimates are available at www.int-res.com/articles/suppl/m333p001_app.pdf).

Based on a similar approach, Srinivasan et al. (2008) also estimated the long-term sustainable catch (MSY), for commercial fish stocks by devising simple, conservative guidelines based on the species' lifespans tmax from published sources and using databases such as FishBase (http://www.fishbase.net), the FAO Fisheries Global Information System (FIGIS), and ARKive's Images of Life on Earth (http://www.arkive.org/species/ARK), as well as the maximum catch over the period $\mathrm{Cmax}$ (based on catch estimates from the Sea Around Us project-Sidebar 1) and selected MSY and catch estimates from the Northeast Fisheries Science Center of the US National Oceanic and Atmospheric Administration (http://www.nefsc.noaa.gov/sos). 
as the "lost valley" technique (Pitcher, 2005; Pitcher and Ainsworth, 2008). For sure, we would not be wise to fish restored ecosystems using today's fishing fleets! A better approach would be for target fishery yields to be guided by the concept of "optimal restorable biomass," an ecosystem-based fishery restoration protocol (Ainsworth and Pitcher, 2008). Sadly, no fishery management of seamounts has yet gone down this restoration-oriented route.

\section{CONCLUSION}

Today, despite considerable recent progress in our understanding of seamount ecology, there is much we do not know; like Lewis Carroll's bemused Bellman, we do not yet fully understand how oceanography and ecology combine to control seamount ecosystems. In the face of this uncertainty, however, using fresh insight from meta-analysis, modeling, and recent field data, we are now able to draw up some initial rules covering how seamounts should be fished and managed sustainably using a precautionary approach (e.g., Morato and Pitcher, 2008). And a few seamounts, at least, need to be fully protected just to enable deeper scientific study. But the evidence put forward here argues that all seamounts need rational management, protection from trawling, and control of other types of fishing if they are not only to provide sustainable fisheries but also to serve as reservoirs of abundance, propagules, and biodiversity (Clark, 2009). Then, seamounts can act out their role as "islands in the deep," sustaining the ocean food web.

\section{REFERENCES}

Agnew, D., J. Pearce, G. Pramod, T. Peatman, R. Watson, J.R. Beddington, and T.J. Pitcher. 2009. Estimating the worldwide extent of illegal fishing. PLoS ONE 4(2):e4570, doi:10.1371/ journal.pone.0004570.

Ainsworth, C., and T.J. Pitcher. 2008. Back to the future in northern British Columbia: Evaluating historic marine ecosystems and optimal restorable biomass as restoration goals for the future. Pp. 317-329 in Reconciling Fisheries With Conservation: Proceedings of the Fourth World Fisheries Congress. J.L. Nielsen, J.J. Dodson, K. Friedland, T.R. Hamon, J. Musick, and E. Verspoor, eds, American Fisheries Society, Symposium 49, Bethesda, MD.

Cheung, W.L., C. Close, V.W.Y. Lam, J. Sarmiento, K. Kearney, R. Watson, and D. Pauly. 2009a. Projections of global marine biodiversity impacts under climate change scenarios. Fish and Fisheries 10(1):1-17.

Cheung, W.W.L., V. Lam, J. Sarmiento, K. Kearney, R. Watson, D. Zeller, and D. Pauly. 2009b. Large-scale redistribution of maximum fisheries catch potential in the global ocean under climate change. Global Change Biology, doi:10.1111/j.1365-2486.2009.01995.x.

Cheung, W.W.L., T.J. Pitcher, and D. Pauly. 2005. A fuzzy logic expert system to estimate intrinsic extinction vulnerabilities of marine fishes to fishing. Biological Conservation 124:97-111.

Cheung, W.W.L., R. Watson, T. Morato, T.J. Pitcher, and D. Pauly. 2007. Intrinsic vulnerability in the global fish catch. Marine Ecology Progress Series 333:1-12.

Clark, M.R. 1999. Fisheries for orange roughy (Hoplostethus atlanticus) on seamounts in New Zealand. Oceanologica Acta 22:593-602.

Clark, M.R. 2009. Deep-sea seamount fisheries: A review of global status and future prospects. Latin American Journal of Aquatic Research 37(3):501-512.

Clark, M.R., and J.A. Koslow. 2007. Impacts of fisheries on seamounts. Pp. 413-441 in Seamounts: Ecology, Fisheries, and Conservation. T.J. Pitcher, T. Morato, P.J.B. Hart, M.R. Clark, N. Haggan, and R.S. Santos, eds, Blackwell Fisheries and Aquatic Resources Series 12, Blackwell Publishing, Oxford.

Clark, M.R., and R. O’Driscoll. 2003. Deepwater fisheries and aspects of their impact on seamount habitat in New Zealand. Journal of Northwest Atlantic Fishery Science 31:441-458.

Clark, M.R., and A.A. Rowden. 2009. Effect of deepwater trawling on the macro-invertebrate assemblages of seamounts on the Chatham Rise, New Zealand. Deep Sea Research Part I 56:1,540-1,554.

Clark, M.R., A.A. Rowden, T. Schlacher, A. Williams, M. Consalvey, K.I. Stocks, A.D. Rogers, T.D. O’Hara, M. White, T.M. Shank, and J. Hall-Spencer. 2010. The ecology of seamounts: Structure, function, and human impacts. Annual Review of Marine Science 2:253-278, doi:10.1146/ annurev-marine-120308-081109.

Clark, M.R., V.I. Vinnichenko, J.D.M. Gordon, G.Z. Beck-Bulat, N.N. Kukharev, and A.F. Kakora. 2007. Large scale distant water trawl fisheries on seamounts. Pp. 361-399 in Seamounts: Ecology, Fisheries, and Conservation. T.J. Pitcher, T. Morato, P.J.B. Hart, M.R. Clark, N. Haggan, and R.S. Santos, eds, Blackwell Fisheries and Aquatic Resources Series 12, Blackwell Publishing, Oxford.

Close, C., W.L. Cheung, S. Hodgson, V. Lam, R. Watson, and D. Pauly. 2006. Distribution ranges of commercial fishes and invertebrates. Pp. 27-37 in Fishes in Databases and Ecosystems. M.L.D. Palomares, K.I. Stergiou, and D. Pauly, eds, Proceedings of the 2006 FishBase Symposium, Fisheries Centre Research Reports, 14(4). Available online at: http://www2.fisheries.com/archive/ publications/reports/report14_4.php (accessed November 25, 2009).

FAO (UN Food and Agriculture Organization). 2008. Report of the Expert Consultation on International Guidelines for the Management of Deep-sea Fisheries in the High Seas. Bangkok, September 11-14, 2007, FAO Fisheries Report No. 855, 39 pp. Available online at: http://www. fao.org/docrep/011/i0003e/i0003e00.HTM (accessed November 25, 2009).

FAO. 2009. International Guidelines for the Management of Deep-sea Fisheries in the High Seas. FAO, Rome, Italy, 73pp.

Francis, R.I.C.C., and M.R. Clark. 2005. Sustainability issues for orange roughy fisheries. Bulletin of Marine Science 76(2):337-351.

Freiwald, A., J.H. Fossa, A. Grehan, T. Koslow, and J.M. Roberts. 2004. Cold-Water Corals: Out of Sight-No Longer Out of Mind. UNEP World Conservation Monitoring Centre, Cambridge, UK, 84 pp.

Fulton, E., T. Morato, and T.J. Pitcher. 2007. Modelling seamount ecosystems and their fisheries. Pp. 296-332 in Seamounts: Ecology, Fisheries, and Conservation. T.J. Pitcher, T. Morato, P.J.B. Hart, M.R. Clark, N. Haggan, and R.S. Santos, eds, Blackwell Fisheries and Aquatic Resources Series 12, Blackwell Publishing, Oxford.

Gage, J.D., J.M. Roberts, J.P. Hartley, and J.D. Humphrey. 2005. Potential impacts of deep-sea trawling on the benthic ecosystem along the northern European continental margin: A review. American Fisheries Society Symposium 41:503-517.

Johnson, K.A. 2002. A Review of National and International Literature on the Effects of Fishing on Benthic Habitats. NOAA Technical Memorandum NMFS-F/SPO-57, 72 pp. 
Kaiser, M.J., K.R. Clarke, H. Hinz, M.C.V. Austen, P.J. Somerfield, and L. Karakassis. 2006. Global analysis of response and recovery of benthic biota to fishing. Marine Ecology Progress Series 311:1-14.

Kitchingman, A., S. Lai, T. Morato, and D. Pauly. 2007. How many seamounts are there and where are they located? Pp. 26-40 in Seamounts: Ecology, Fisheries, and Conservation. T.J. Pitcher, T. Morato, P.J.B. Hart, M.R. Clark, N. Haggan, and R.S. Santos, eds, Fish and Aquatic Resources Series, Blackwell, Oxford, UK.

Koslow, T. 2007. The Silent Deep: The Discovery, Ecology and Conservation of the Deep Sea. University of Chicago Press, Chicago, IL, 288 pp.

Koslow, J.A., K. Gowlett-Holmes, J.K. Lowry, T. O'Hara, G.C.B. Poore, and A. Williams. 2001. Seamount benthic macrofauna off southern Tasmania: Community structure and impacts of trawling. Marine Ecology Progress Series 213:111-125.

Marques da Silva, H., and M.R. Pinho. 2007. Small-scale fishing on seamounts. Pp. 535-360 in Seamounts: Ecology, Fisheries, and Conservation. T.J. Pitcher, T. Morato, P.J.B. Hart, M.R. Clark, N. Haggan, and R.S. Santos, eds, Fish and Aquatic Resources Series, Blackwell, Oxford, UK.

Mora, C., R.A. Myers, M. Coll, S. Libralato, T.J. Pitcher, R.U. Sumaila, D. Zeller, R. Watson, K.J. Gaston, and B. Worm. 2009. Management effectiveness of the world's marine fisheries. PloS Biology 7(6):e1000131, doi:10.1371/ journal.pbio.1000131.

Morato, T., and T.J. Pitcher. 2008. Reconciling fisheries with conservation on seamounts. Pp. 1,623-1,634 in Reconciling Fisheries with Conservation: Proceedings of the Fourth World Fisheries Congress. J.L. Nielsen, J.J. Dodson, K. Friedland, T.R. Hamon, J. Musick, and E. Verspoor, eds, American Fisheries Society, Symposium 49, Bethesda, MD.

Morato, T., C. Bulman, and T.J. Pitcher. 2009. Modelled effects of primary and secondary production enhancement by seamounts on local fish stocks. Deep-Sea Research Part II 56:2,713-2,719.

Morato, T., W.L. Cheung, and T.J. Pitcher. 2006a. Vulnerability of seamount fish to fishing: Fuzzy analysis of life history attributes. Journal of Fish Biology 68(1):209-221.

Morato, T., D.A. Varkey, C. Damaso, M. Machete, M. Santos, R. Prieto, R.S. Santos, and T.J. Pitcher. 2008. Evidence of a seamount effect on aggregating visitors. Marine Ecology Progress Series 357:23-32.

Morato, T., R. Watson, T.J. Pitcher, and D. Pauly. 2006b. Fishing down the deep. Fish and Fisheries 7(1):24-34.

NMFS (National Marine Fisheries Service). 2005. Pacific Coast Groundfish Fishery Management Plan; Essential Fish Habitat Designation and Minimization of Adverse Impacts; Final
Environmental Impact Statement: NOAA NMFS Northwest Region, Seattle, WA, USA. Available online at: http://www.pcouncil. org/groundfish/gffmp/gfa19.html (accessed November 25, 2009).

Pitcher, T.J. 2005. Back to the future: A fresh policy initiative for fisheries and a restoration ecology for ocean ecosystems. Philosophical Transactions of the Royal Society 360:107-121.

Pitcher, T.J., and C. Ainsworth. 2008. Back to the future: A candidate ecosystem-based solution to the fisheries problem. Pp. 365-383 in Reconciling Fisheries with Conservation: Proceedings of the Fourth World Fisheries Congress. J.L. Nielsen, J.J. Dodson, K. Friedland, T.R. Hamon, J. Musick, and E. Verspoor, eds, American Fisheries Society, Symposium 49, Bethesda, MD.

Pitcher, T.J., and C. Bulman. 2007. Raiding the larder: A quantitative evaluation framework and trophic signature for seamount food webs. Pp. 282-295 in Seamounts: Ecology, Fisheries, and Conservation. T.J. Pitcher, T. Morato, P.J.B. Hart, M.R. Clark, N. Haggan, and R.S. Santos, eds, Fish and Aquatic Resources Series 12, Blackwell, Oxford, UK.

Pitcher, T.J., D. Kalikoski, G. Pramod, and K. Short. 2009. Not honouring the code. Nature 457:658-659.

Pitcher, T.J., T. Morato, P.J.B. Hart, M.R. Clark, N. Haggan, and R.S. Santos. 2007. The depths of ignorance: An ecosystem evaluation framework for seamount ecology, fisheries and conservation. Pp. 476-488 in Seamounts: Ecology, Fisheries, and Conservation. T.J. Pitcher, T. Morato, P.J.B. Hart, M.R. Clark, N. Haggan, and R.S. Santos, eds, Fish and Aquatic Resources Series 12, Blackwell, Oxford, UK.

Probert, P.K. 1999. Seamounts, sanctuaries and sustainability: Moving towards deep-sea conservation. Aquatic Conservation: Marine and Freshwater Ecosystems 9:601-605.

Probert, P.K., S. Christiansen, K.M. Gjerde, S. Gubbay, and R.S. Santos. 2007. Management and conservation of seamounts. Pp. 442-475 in Seamounts: Ecology, Fisheries, and Conservation. T.J. Pitcher, T. Morato, P.J.B. Hart, M.R. Clark, N. Haggan, and R.S. Santos, eds, Fisheries and Aquatic Resources Series 12, Blackwell Publishing, Oxford, UK.

Rogers, A.D, A. Baco, H. Griffiths, T. Hart, and J.M. Hall-Spencer. 2007. Corals on seamounts. Pp. 141-169 in Seamounts: Ecology, Fisheries, and Conservation. T.J. Pitcher, T. Morato, P.J.B. Hart, M.R. Clark, N. Haggan, and R.S. Santos, eds, Blackwell Fisheries and Aquatic Resources Series 12, Blackwell Publishing, Oxford, UK.

Rogers, A.D., M.R. Clark, J.M. Hall-Spencer, and K.M. Gjerde. 2008. The Science Behind the Guidelines: A Scientific Guide to the FAO Draft International Guidelines (December 2007) for the Management of Deep-Sea Fisheries in the High
Seas and Examples of How the Guidelines May Be Practically Implemented. International Union for Conservation of Nature, Gland, Switzerland.

Sasaki, T. 1986. Development and present status of Japanese trawl fisheries in the vicinity of seamounts. Pp. 21-30 in Environment and Resources of Seamounts in the North Pacific. R.N. Uchida, S. Hayasi, and G.W. Boehlert, eds, US Department of Commerce, NOAA Technical Report NMFS 43.

Srinivasan, U.T., S.P. Carey, E. Hallstein, P.A.T. Higgins, A.C. Kerr, L.E. Koteen, A.B. Smith, R. Watson, J. Harte, and R.B. Norgaard. 2008. The distribution of ecological impacts from human activities over 1961-2000 and the debt of nations. Proceedings of the National Academy of Sciences of the United States of America 105:1,768-1,773.

Vinnichenko, V.I. 2002. Prospects of fisheries on the seamounts. ICES CM 2002/M:32.

Waller, R., L. Watling, P. Auster, and T. Shank. 2007. Anthropogenic impacts on the Corner Rise seamounts, north-west Atlantic Ocean. Journal of the Marine Biological Association of the UK 87:1,075-1,076.

Watling, L., and E.A. Norse. 1998. Disturbance of the sea bed by mobile fishing gear: A comparison to forest clearcutting. Conservation Biology 12(6):1,180-1,197.

Watson, R., A. Kitchingman, and W. Cheung. 2007. Catches from world seamount fisheries. Pp. 400-412 in Seamounts: Ecology, Fisheries, and Conservation. T.J. Pitcher, T. Morato, P.J.B. Hart, M.R. Clark, N. Haggan, and R.S. Santos, eds, Fish and Aquatic Resources Series, Blackwell, Oxford, UK.

Watson, R., A. Kitchingman, A. Gelchu, and D. Pauly. 2004. Mapping global fisheries: Sharpening our focus. Fish and Fisheries 5:168-177.

Ware, D.M. 2000. Aquatic ecosystems: Properties and models. Pp. 161-194 in Fisheries Oceanography: An Integrative Approach to Fisheries Ecology and Management. P.J. Harrison and T.R. Parsons, eds, Blackwell Science, Oxford, UK.

Wessel, P. 2007. Seamount characteristics. Pp. 3-25 in Seamounts: Ecology, Fisheries, and Conservation. T.J. Pitcher, T. Morato, P.J.B. Hart, M.R. Clark, N. Haggan, and R.S. Santos, eds, Fish and Aquatic Resources Series 12, Blackwell, Oxford, UK.

Zeller, D., and D. Pauly, eds. 2007. Reconstruction of Marine Fisheries Catches for Key Countries and Regions (1950-2005). Fisheries Centre Research Reports 15(2), 163 pp. Available online at: http://www2.fisheries.com/archive/ publications/reports/report15_2.php (accessed November 25, 2009). 